\title{
Optimizing Virtual Water as Irrigation Water Management Strategy in Egypt
}

\author{
Ahmed H. Ibrahim ${ }^{1}$ \\ ${ }^{l}$ Assistant Professor, Dept. of Construction Engineering, Faculty of Engineering, Zagazig University, Egypt.
}

\begin{abstract}
Egypt is known as one of the oldest agricultural civilizations; the River Nile allowed a sedentary agricultural society to develop thousands of years ago. Egypt is located in the hyper arid climatic zone, where rainfall is scarce and the desert covers most of the land. In addition to its fixed Nile quota, a deep nonrenewable groundwater reservoirmay be utilized with a rate of 2.7 Billion cubic meters per year ( $\mathrm{bm}^{3}$ lyear) over a period of 100 years. The water shortage is the main constraint and a major limiting factor facing the implementation of the country future economy. In this paper, the linear programming techniques have been used to minimize the virtual water of the current cropping pattern. The study proposed a cropping pattern can economized in water requirements and cultivated areas besides achieve the same level each crop production gained at the current status. The proposed scenario decreased the objective function by $5.59 \%$, the total cultivated area decreased by 204 thousand feddans, and the total water requirements decreased by 503 million cubic meters.
\end{abstract}

Keywords: Optimization, Virtual Water, Linear programming, Water resources management, Cropping Pattern.

\section{Introduction}

Egypt is in the north-eastern corner of Africa between latitudes $21^{\circ}$ and $31^{\circ}$ North and longitudes $25^{\circ}$ and $35^{\circ}$ East with a total area of one million km2; the country stretches 1.1 thousand kilometer from north to south and up to 1.13 thousand kilometer from east to west. It is bordered in the north by the Mediterranean Sea, in the east by the Red Sea, in the south by Sudan and in the west by Libya.

Egypt is known as one of the oldest agricultural civilizations; the River Nile allowed a sedentary agricultural society to develop thousands of years ago. The country has no effective rainfall except in a narrow band along the northern coast. Consequently, Egypt has only one main source of water supply, the Nile. The availability of a reliable water supply from the High Dam in Aswan is governed by the water sharing treaty with the countries of the Nile Basin under which 55.5 billion m3 per annum is allocated to Egypt. Additional water could become available with the completion of the Jonglei Canal [1].

Egypt is located in the hyper arid climatic zone, where rainfall is scarce and the desert covers most of the land. In addition to its fixed Nile quota, a deep non-renewable groundwater reservoir may be utilized with a rate of 2.7 billion cubic meters per year $\left(\mathrm{bm}^{3} / \mathrm{year}\right)$ over a period of 100 years. The higher the exploitation rate, the shorter the period of use will be. Egypt is trying to satisfy its water needs, which are $25 \%$ higher than the available water resources, through recycling of agriculture wastewater and trapping water losses. The water shortage is the main constraint and a major limiting factor facing the implementation of the country future economy [2].

According to the Egyptian national plan, distribution of Nile water use in Egypt for theyear 2017, total water demand in Egypt isestimated at $87.9 \mathrm{bm}^{3}$, representing a $30 \%$ increase over current consumption. The majorcontributor to this increase is in the agriculture sector. Egypt is entering into newagricultural development projects to expand the cultivatable area from 7.5 million to 11 million feddan, representing an overall increase of 3.4 million feddan[2].

Virtual water is the amount of water that is embedded in food or other products needed for its production. For example, to produce one kilogram of wheat we need about 1,000 liters of water(i.e. the virtual water of this kilogram of wheat is 1,000 liters), meat needs about five to ten times more. The per capita consumption of virtual water contained in our diets varies according to the type of diets, from $1 \mathrm{~m} 3 /$ day for a survival diet, to $2.6 \mathrm{~m} 3 /$ day for a vegetarian diet and over $5 \mathrm{~m} 3$ for a USA style meat based diet [3].

The concept of virtual water (VW) was introduced by Allan in 1993 as an economic tool for assessing the globalization of water resources through trade [4]. Virtual water was defined as the amount of water used in the exporting country to produce a given good or service [5].

In 2011 Alaa El-Sadek concluded that, there is a possibility for the application of the virtual water concept on the national level taking into account water endowments, and other natural and social economic conditions. The virtual water strategy seeks ways to consciously and efficiently utilize the internal and external water resources to alleviate water scarcity. This, however, by no means implies that importing food is the only 
response the water scarce countries and regions should and can take. Other measures concerning the supply and demand sides of water management are imperative. The argument here is that the virtual water strategy should be an integral component in the whole package of integrated water re-sources management [6].

\section{Egypt's Water Resources}

The Nile supplies $96 \%$ of Egypt's fresh water. It is the longest river in the world ,flowing approximately $6,800 \mathrm{~km}$ from south to north. Its headwaters stem from theRuvyironza River in Burundi. The Nile finally ends its journey in the Nile Delta andthe Mediterranean Sea. The river basin includes ten countries: Rwanda, Burundi, Democratic Republic of the Congo (DRC), Tanzania, Kenya, Uganda, Ethiopia, Eritrea, South Sudan, Sudan and Egypt [7].

According to the Egyptian national plan, distribution of Nile water use in Egypt for theyear 2008-2009 is approximately $70.23 \mathrm{bm}^{3}$, comprising of agricultural, Loss by Evaporation, Household Uses, industrial andRivers Navigation demand of 60.0, 2.1, 6.6, 1.33 and $0.2 \mathrm{bm}^{3}$ respectively as shown in Table 1 . The added $14.73 \mathrm{bm}^{3}$ water use over the released water from the Aswan High Dam (70.23-55.5) comes fromUnderground water in Valley \& Delta $\left(6.2 \mathrm{bm}^{3}\right)$, Agricultural sewage water recycling $\left(8.0 \mathrm{bm}^{3}\right)$, Sewage water recycling $(1.3$ $\left.\mathrm{bm}^{3}\right)$, Rains \& Floods $\left(1.3 \mathrm{bm}^{3}\right)$, and Sea water desalination $\left(0.06 \mathrm{bm}^{3}\right)$. Agriculture consumes nearly82.3\% of Egypt's share of River Nile. In the year 2012, total water consumption in Egypt was75.5 $\mathrm{bm}^{3}$. Egypt is entering into newagricultural development projects to expand the cultivatable area from 7.5 million to 11 million feddan, representing an overall increase of 3.4 million feddan[8].

Table 1: Water consumption from the Nile River, 2009 and 2012, Egypt[8]

\begin{tabular}{|l|l|l|}
\hline Sector & $\begin{array}{l}\text { Consumption } \mathbf{2 0 0 9} \\
\left(\mathbf{b m}^{\mathbf{3}}\right)\end{array}$ & $\begin{array}{l}\text { Consumption } \\
\left(\mathbf{b m}^{\mathbf{3}}\right)\end{array}$ \\
\hline Agriculture & 60.0 & 62.1 \\
\hline Loss by Evaporation from The Nile \&Canals & 2.1 & 2.5 \\
\hline Household Uses & 6.6 & 9.7 \\
\hline Industry & 1.33 & 1.2 \\
\hline Rivers Navigation & 0.2 & 0 \\
\hline Total water consumption & $\mathbf{7 0 . 2 3}$ & $\mathbf{7 5 . 5}$ \\
\hline
\end{tabular}

Current supply from Share of River Nile water, Underground water in Valley \& Delta, Agricultural sewage water recycling, Sewage water recycling, Rains \& Floods, and Sea water desalination is approximately $70.53 \mathrm{bm}^{3}$ per year as shown in Table 2.This implies a supply gap of $5.0 \mathrm{bm}^{3}$. Opportunities to increase the water supply are limited. Due to the intensive useof irrigated land and the expected increases in demand for water for all uses, it is clearthat unless action is taken, future demand for river water will greatly outweigh thesupply. Water savings offer a partial solution to this problem [8].

Table 2: Available water resources, 2009 and 2012, Egypt [8]

\begin{tabular}{|l|l|l|}
\hline Water Supply Source & $\left(\mathbf{b m}^{\mathbf{3}}\right)$ & Supply 2009 \\
\hline Share of River Nile water & 55.5 & 55.5 \\
\hline Underground water in Valley \& Delta & 6.2 & 7.5 \\
\hline Agricultural sewage water recycling & 8.0 & 5.2 \\
\hline Sewage water recycling & 1.3 & 1.3 \\
\hline Rains \& Floods & 1.3 & 0.97 \\
\hline Sea water desalination & 0.06 & 0.06 \\
\hline Total available Waterin 2009-2012 & $\mathbf{7 2 . 3 6}$ & $\mathbf{7 0 . 5 3}$ \\
\hline
\end{tabular}

\section{Egypt's Agriculture}

In Egypt, Agriculture is almost entirely dependent on irrigation from the Nile since there is no significant rainfall except in a narrow strip along the Mediterranean coast. The agricultural land base consists of old land in the Nile Valley and Delta, rain fed areas, several oases, and lands reclaimed from the desert since 1952 (the New Lands). The total area of irrigated land in year 2000 was approximately 7.7 million feddans and expected to be 11 million feddans by the year 2017 due to horizontal expansion and the implementation of the two mega projects of El-Salam Canal at North Sinai and Toshka at south valley [9]. As shown in Table 3, the total cultivated area increased from 7,946 thousand feddans in year 2001 to 8,799 thousand feddans in year 2012.

Agriculture is a major economic activity in Egypt. The agricultural sector represents $13.22 \%$ of the GDP year 2008 (down from 40\% in 1960), it provides employment for about 34\% of the labour force and plays an important role for many people as sustenance farming. Population growth in combination with the horizontal expansion plans of the government will increase the demand for irrigation water. A considerable increase in efficiency is needed to make this additionally needed water available. Such an efficiency improvement will have important social as well as economic impacts [10]. 
Table 3: Total cultivated area $(2001-2012)[8]$

\begin{tabular}{|l|l|}
\hline Year & $\begin{array}{l}\text { Total Cultivated Area } \\
\text { ('000 Feddan ) }\end{array}$ \\
\hline 2001 & 7946 \\
\hline 2002 & 8148 \\
\hline 2003 & 8113 \\
\hline 2004 & 8279 \\
\hline 2005 & 8385 \\
\hline 2006 & 8411 \\
\hline 2007 & 8423 \\
\hline 2008 & 8432 \\
\hline 2009 & 8783 \\
\hline 2010 & 8741 \\
\hline 2011 & 8619 \\
\hline 2012 & 8799 \\
\hline
\end{tabular}

There are many different crops are cultivated in Egypt. The most important crops grown in Egypt are :

- Cereals: rice, wheat and maize are the major field crops

- Fiber crops: cotton has traditionally been the most important fiber crop in Egypt ,

- Sugar crops: sugar cane is the main sugar crop in Upper Egypt. sugar beet also grows in large areas in the Nile delta, and contributes to the sugar industry in Egypt,

- Legumes: these include a number of bean crops that are used for human consumption, such as broad beans and soybeans

- Forage crops: Egyptian clover, berseem, is the major winter forage crop cultivated in the Nile Valley and delta. It is the most widely grown field crop.

- Fruits: citrus, primarily oranges that represent 85 percent of total citrus production, makes up 50 percent of total fruit production. The fruit-planted area has expanded over the last three decades. Other subtropical fruits are also grown in Egypt,

- Vegetables: Different vegetables are cultivated all over the entire country. The most important vegetables are cabbage, cucumber, garlic, onion, potato, pepper, tomato, and eggplant.

\section{Research Objective}

The main objective of the current paper is to minimize the virtual water in Egypt through an optimized new cropping pattern which could decrease the total water requirements needed for cultivating the proposed cropping pattern with the same level of the current production to satisfy the current market needs and also achieve reasonable net return from the proposed cropping pattern. The virtual water trade will be applied between the three different zones of Egypt (Lower, Middle, and Upper Egypt).

\section{Methodology}

Six main steps were carried out to achieve the objective of this paper. The steps were:

i) Determining the study area,

ii) Collecting varies data and information,

iii) Calculating the virtual water for different crops,

iv) Proposing scenario to minimize the virtual water inside the Nile valley,

v) Developing optimization model, and.

vi) Analyzing the results due to applying the proposed cropping pattern.

\section{Study Area}

The objective of this study will be applied inside the Nile valley in Egypt. The nile valley is divided into three zones, Lower Egypt (Alexandreia, Behera, Gharbia, Kafr El-sheikh, Dakhlia, Damietta, Sharkia, Ismalia, Port Said, Suez, Menofia, Qaliobia, and Cairo), Middle Egypt (Giza, BeniSuef, Fayoum, and Menia), and Upper Egypt (Assuit, Suhag, Qena, Luxor, and Aswan). The production of each zone will be traded with the other two zones to achieve the all needs inside the Nile valley and achieve the main objective of this study. Fig1 shows the different governorates in Egypt. 


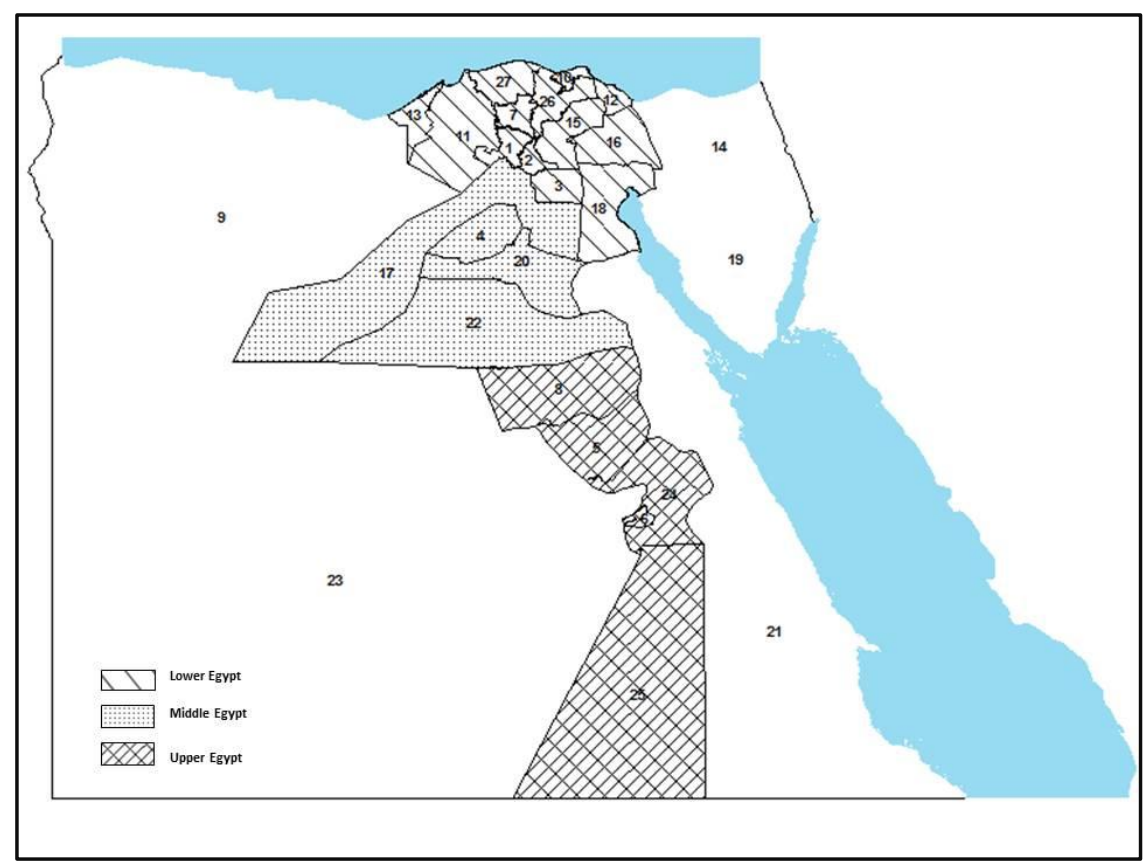

Fig. 1: Egypt governorates on a map

\section{The Current Cropping Pattern In Egypt}

There are three cropping seasons in Egypt: Winter (November to May), summer (April/ May to October) and "Nil" (July/August to October). Table 4 shows the current cropping pattern inside the Nile valley in Egypt for main 13 crops which are selected to achieve the purpose of the study. Crops were choosed based on their importance to decision makers and the availability of data. The crops selected for the Winter, Summer and Nili seasons respectively account for almost $82 \%, 70 \%$ and $65 \%$ of the total cropped area of the three seasons.

The cropping pattern structure of winter crops could be represented by Fig 2. Wheat has had the highest relative importance among winter crops, accounting for approximately half of the total cropped area in winter season $(53.31 \%)$. The total cultivated area with wheat was 2.9 million feddans as shown in Table 4 . In summer season, Maize occupied about $45 \%$ of the total cropped area in summer season followed by rice which occupied about $32 \%$ of the total cultivated area in summer season as shown in Fig 3. The total cultivated area of maize and rice inside the Nile valley in summer season was 2.1 and 2.4 million feddans respectively as shown in Table 4. Maize also has had the highest relative importance among nili crops, accounting for approximately $76 \%$ of the total cropped area in nili season as shown in Fig 4. The total cropped area with maize in nili season was 295 thousand feddans.

Table 4: Cropping pattern structure in Egypt seasonally [11]

\begin{tabular}{|c|c|c|c|c|}
\hline \multirow[b]{2}{*}{ Crop } & \multicolumn{4}{|c|}{ Cultivated area (Fed) } \\
\hline & Lower & Middle & Upper & Total \\
\hline \multicolumn{5}{|l|}{ Winter } \\
\hline Wheat & $1,799,987$ & 570,148 & 564,673 & $2,934,808$ \\
\hline Barley & 33,478 & 7,096 & 2,567 & 43,141 \\
\hline Broadbean & 59,768 & 3,043 & 9,864 & 72,675 \\
\hline Sugarbeet & 323,778 & 74,541 & 6,827 & 405,146 \\
\hline Clover & 926,304 & 291,566 & 162,077 & $1,379,947$ \\
\hline Tahresh & 258,754 & 49,505 & 13,896 & 322,155 \\
\hline Potatoes & 143,359 & 25,415 & 2,189 & 170,963 \\
\hline Tomatos & 65,826 & 53,352 & 57,323 & 176,501 \\
\hline \multicolumn{5}{|l|}{ Summer } \\
\hline Rice & $1,466,426$ & 1,431 & 0 & $1,467,857$ \\
\hline Maize & $1,053,619$ & 634,209 & 379,866 & $2,067,694$ \\
\hline peanuts & 48,529 & 19,107 & 9,361 & 76,997 \\
\hline Sugarcane & 3,153 & 42,155 & 279,984 & 325,292 \\
\hline Cotton & 291,551 & 28,652 & 6,372 & 326,575 \\
\hline Tomatoes & 107,908 & 39,610 & 11,682 & 159,200 \\
\hline Potatoes & 126,273 & 17,931 & 911 & 145,115 \\
\hline \multicolumn{5}{|l|}{ Nili } \\
\hline Maize & 135,910 & 110,042 & 48,901 & 294,853 \\
\hline Tomatoes & 7,367 & 27,587 & 4,945 & 39,899 \\
\hline Potatoes & 11,823 & 41,857 & 1,673 & 55,353 \\
\hline
\end{tabular}




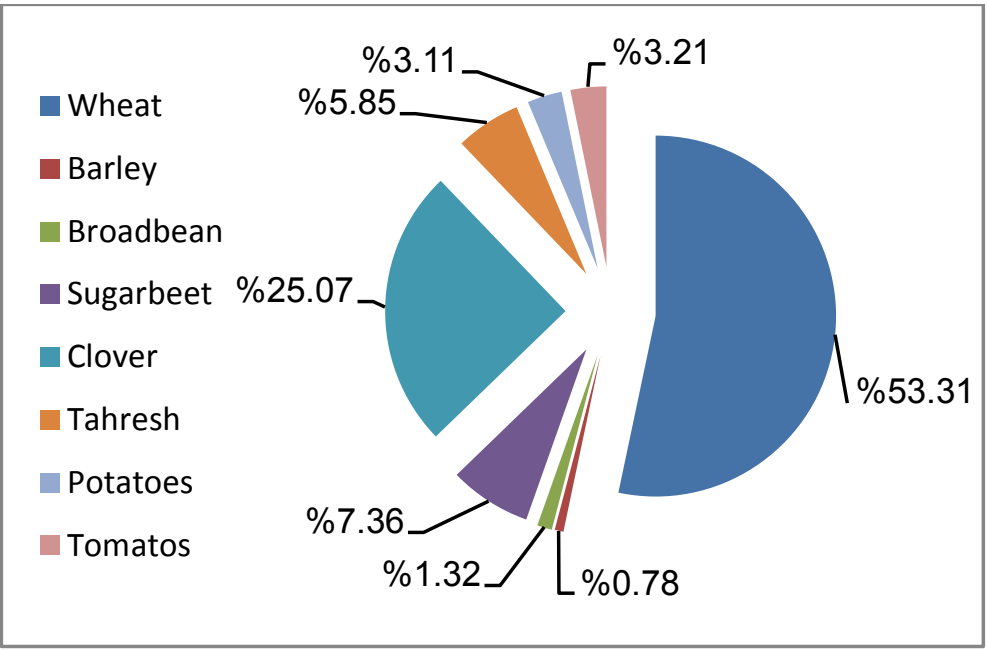

Fig. 2: Cropping pattern structure of winter crops in Egypt

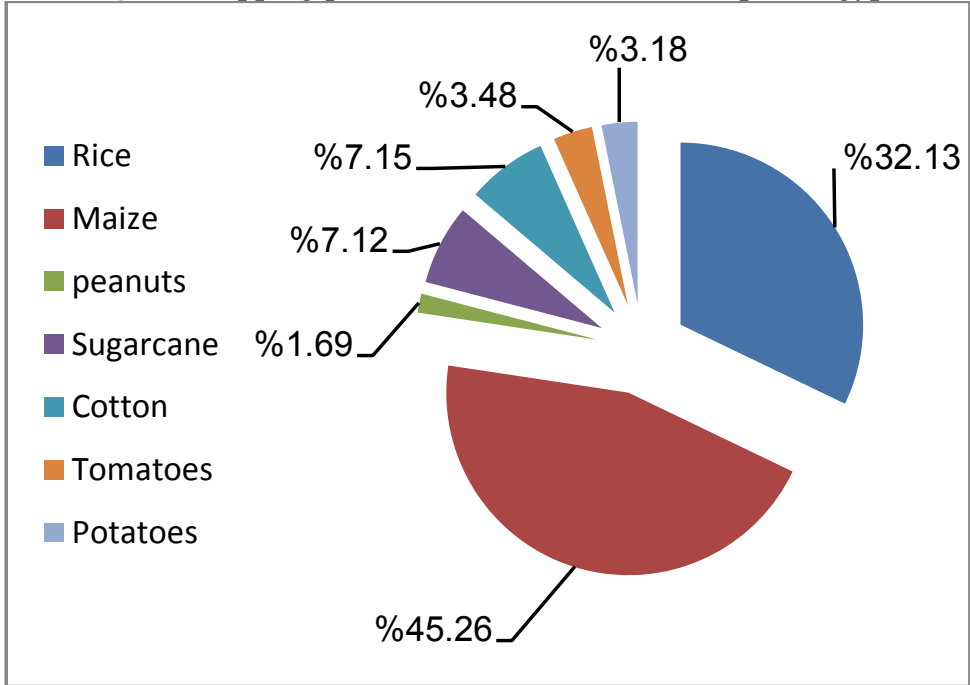

Fig. 3: Cropping pattern structure of summer crops in Egypt

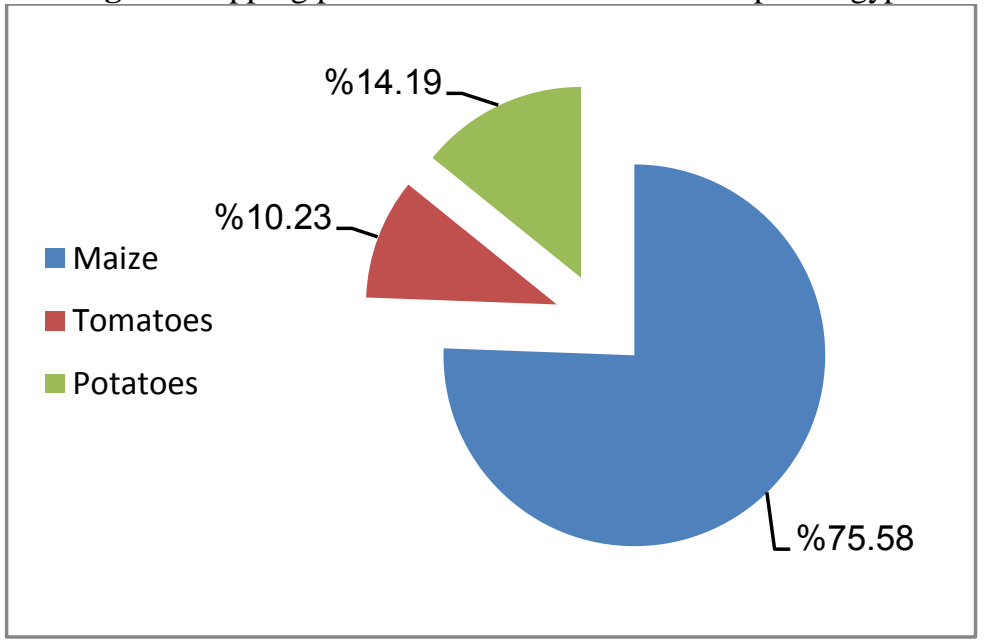

Fig. 4: Cropping pattern structure of nili crops in Egypt

\section{Current Production Of Main Crops And Self Sufficiency}

The production of the current cropping pattern was counting as shown in Table 5. The production of wheat was 8.2 million ton, while rive has had a production of 5.8 million tons inside the Nile valley. The current cropping pattern produced about 8.9 million tons of maize in the summer season only and 789 thousand tons in the nili season. The sugarcane and sugarbeet production were 15.5 and 8.8 million tons respectively. This 
production didn't achieved self-sufficiency in Egypt from previously mentioned crops so it is very important to achieve self-sufficiency in Egypt especially from strategic crops.

Table 5: Current production of main crops in Egypt seasonally [11]

\begin{tabular}{|c|c|c|c|c|}
\hline \multirow{2}{*}{ Crop } & \multicolumn{4}{|c|}{ Production (Ton) } \\
\hline & Lower & Middle & Upper & Total \\
\hline \multicolumn{5}{|l|}{ Winter } \\
\hline Wheat & $5,067,715$ & $1,620,259$ & $1,555,321$ & $8,243,295$ \\
\hline Barley & 52,329 & 10,600 & 3,172 & 66,101 \\
\hline Broadbean & 82,807 & 3,464 & 12,446 & 98,718 \\
\hline Sugarbeet & $6,840,393$ & $1,754,234$ & 219,106 & $8,813,733$ \\
\hline Clover & $27,329,008$ & $7,127,443$ & $4,899,185$ & $39,355,637$ \\
\hline Tahresh & $3,438,572$ & 455,507 & 149,239 & $4,043,318$ \\
\hline Potatoes & $1,540,077$ & 268,279 & 41,533 & $1,849,889$ \\
\hline Tomatos & $1,161,631$ & 879,255 & $1,132,320$ & $3,173,206$ \\
\hline \multicolumn{5}{|l|}{ Summer } \\
\hline Rice & $5,877,124$ & 5,208 & 0 & $5,882,332$ \\
\hline Maize & $3,792,241$ & $1,946,052$ & $1,155,039$ & $6,893,332$ \\
\hline peanuts & 69,530 & 26,658 & 9,992 & 106,180 \\
\hline Sugarcane & 118,020 & $1,915,969$ & $13,512,043$ & $15,546,032$ \\
\hline Cotton & 257,343 & 24,583 & 6,458 & 288,384 \\
\hline Tomatoes & $1,820,086$ & 671,293 & 178,731 & $2,670,110$ \\
\hline Potatoes & $1,597,174$ & 193,017 & 13,206 & $1,803,397$ \\
\hline \multicolumn{5}{|l|}{ Nili } \\
\hline Maize & 405,841 & 273,419 & 110,042 & 789,302 \\
\hline Tomatoes & 94,675 & 470,085 & 95,997 & 660,757 \\
\hline Potatoes & 106,907 & 408,561 & 25,350 & 540,818 \\
\hline
\end{tabular}

The self-sufficiency Percentage for Some Food Commodities showed in Table 6. Egypt lags behind in achieving self-sufficiency in strategic food commodities. The self-sufficiency ratios of wheat, maize and beans reached $55.7 \%, 67.7 \%$ and $38.8 \%$ respectively. In the year 2012, Egypt was the world's top wheat and broad bean importer, the fourth largest importer of maize.

Table 6: Self-sufficiency percentage for some food commodities [11]

\begin{tabular}{|l|l|}
\hline Food Commodities & Self-sufficiency \% \\
\hline Wheat & 55.7 \\
\hline Maize & 67.7 \\
\hline Rice & 102.3 \\
\hline Beans & 38.8 \\
\hline Lentil & 1.6 \\
\hline Potatoes & 109 \\
\hline Fresh Vegetables & 101.2 \\
\hline Citrus & 134.9 \\
\hline Fresh Fruits & 98.5 \\
\hline
\end{tabular}

Two fundamental factors contribute to Egypt's food security challenge: the rapidly growing population; and the limited availability of agricultural land. The escalating demand for food in Egypt stems from a population that has almost tripled in size during the last 50 years. Population in Egypt reached almost 87 million in 2013 up from 29 million in 1960; and is currently growing at an average rate of $1.8 \%$ annually .Meanwhile, agricultural land has increased by only 50\% during the same period [12].

\section{Virtual Water}

Virtual water trade (also known as trade in embedded or embodied water) refers to the hidden flow of water if food or other commodities are traded from one place to another. For instance, it takes 1,600 cubic meters of water on average to produce one metric ton of wheat. The precise volume can be more or less depending on climatic conditions and agricultural practice. Hoekstra and Chapagain have defined the virtualwater content of a product (a commodity, good or service) as "the volume of freshwater used to produce the product, measured at the place where the product was actually produced" [13]. Mathematically the virtual water could be expressed using the Eq. 1:

Virtual water $\left(\frac{\mathrm{m}^{3}}{\text { Ton }}\right)=\frac{\text { Water Requirements }\left(\frac{\mathrm{m}^{3}}{\mathrm{Fed}}\right)}{\operatorname{Vield}\left(\frac{\text { Ton }}{\text { Fed }}\right)}$

\subsection{Water Requirements}

The ICID (2000) describes it as the "total water needed for evapotranspiration, from planting to harvest for a given crop in a specific climate regime, when adequate soil water is maintained by rainfall and/or irrigation so that it does not limit plant growth and crop yield" [14]. The water requirements of same crop differ from region to another in Egypt as shown in Table 7. The water requirements of wheat in lower, middle, upper Egypt 
were 1720, 1901, 2355 cubic meter per feddan respectively and for rice were1340, 1170, and 1534 cubic meter per feddan respectively. Therefore, the water requirements in the Upper Egypt were the highest for all crops because of the high temperature in this region.

\subsection{Crop Yield (Land Productivity)}

In agriculture, crop yield refers to both the measure of the yield of a crop per unit area of land cultivation. Table 8 showed the yield of main crops inside the Nile valley in Egypt. It could be noticed that crop yield of the same crop had different values in the three zones (lower, middle, and upper) due to the quality of land and the suitability of the climatic to the cultivated crop. The yield of sugarbeet was $21.127,23.534$, and 32.094 ton per feddan in the lower, middle, and upper Egypt respectively. This variance means that we can produce more from sugar beet in upper Egypt more than lower and middle Egypt.

Table 7: Crop water requirements and yield in Egypt [11]

\begin{tabular}{|c|c|c|c|}
\hline \multirow{2}{*}{ Crop } & \multicolumn{3}{|c|}{ Water Requirements $\left(\mathrm{m}^{3} /\right.$ Fed $)$} \\
\hline & Lower & Middle & Upper \\
\hline \multicolumn{4}{|l|}{ Winter } \\
\hline Wheat & 1720 & 1901 & 2355 \\
\hline Barley & 1480 & 1487 & 1888 \\
\hline Broadbean & 1339 & 1437 & 1886 \\
\hline Sugarbeet & 2419 & 2394 & 3098 \\
\hline Clover & 2875 & 3215 & 4041 \\
\hline Tahresh & 1340 & 1170 & 1534 \\
\hline Potatoes & 2175 & 2284 & 2439 \\
\hline Tomatos & 2175 & 2284 & 2439 \\
\hline \multicolumn{4}{|l|}{ Summer } \\
\hline Rice & 1340 & 1170 & 1534 \\
\hline Maize & 2904 & 2677 & 3243 \\
\hline peanuts & 3889 & 6984 & 7682 \\
\hline Sugarcane & 7220 & 8211 & 9964 \\
\hline Cotton & 3292 & 3696 & 4215 \\
\hline Tomatoes & 2967 & 3487 & 3988 \\
\hline Potatoes & 2967 & 3487 & 3988 \\
\hline \multicolumn{4}{|l|}{ Nili } \\
\hline Maize & 2377 & 2677 & 3243 \\
\hline Tomatoes & 2551 & 2851 & 3631 \\
\hline Potatoes & 2551 & 2851 & 3631 \\
\hline
\end{tabular}

Now, the virtual water of each crop in different seasons could be calculated as shown in Table 8 . The virtual water of wheat was 611, 669, and 855 cubic meter per ton in lower, middle, and upper Egypt respectively this means that cultivating wheat in lower Egypt required less water than middle and upper Egypt and so on for the other crops. Through using the optimization it could be minimize the virtual water of all crops during the whole year to produce the same production of all crops as current and saves water as well.

Table 8: Virtual water of main cultivated crops inside the Nile valley.

\begin{tabular}{|c|c|c|c|c|c|c|}
\hline \multirow{2}{*}{ Crop } & \multicolumn{3}{|c|}{ Yield (Ton/Fed) } & \multicolumn{3}{|c|}{ Virtual water $\left(\mathrm{m}^{3} /\right.$ ton$)$} \\
\hline & Lower & Middle & Upper & Lower & Middle & Upper \\
\hline \multicolumn{7}{|l|}{ Winter } \\
\hline Wheat & 2.815 & 2.842 & 2.754 & 611 & 669 & 855 \\
\hline Barley & 1.563 & 1.494 & 1.236 & 947 & 995 & 1528 \\
\hline Broadbean & 1.385 & 1.138 & 1.262 & 966 & 1262 & 1495 \\
\hline Sugarbeet & 21.127 & 23.534 & 32.094 & 114 & 102 & 97 \\
\hline Clover & 29.503 & 24.445 & 30.228 & 97 & 132 & 134 \\
\hline Tahresh & 13.289 & 9.201 & 10.740 & 101 & 127 & 143 \\
\hline Potatoes & 10.743 & 10.556 & 18.974 & 202 & 216 & 129 \\
\hline Tomatos & 17.647 & 16.480 & 19.753 & 123 & 139 & 123 \\
\hline \multicolumn{7}{|l|}{ Summer } \\
\hline Rice & 4.008 & 3.639 & 0.000 & 334 & 321 & 0 \\
\hline Maize & 3.599 & 3.068 & 3.041 & 807 & 872 & 1067 \\
\hline peanuts & 1.433 & 1.395 & 1.067 & 2714 & 5006 & 7197 \\
\hline Sugarcane & 37.431 & 45.451 & 48.260 & 193 & 181 & 206 \\
\hline Cotton & 0.883 & 0.858 & 1.013 & 3730 & 4308 & 4159 \\
\hline Tomatoes & 16.867 & 16.948 & 15.300 & 176 & 206 & 261 \\
\hline Potatoes & 12.649 & 10.764 & 14.496 & 235 & 324 & 275 \\
\hline \multicolumn{7}{|l|}{ "Nili } \\
\hline Maize & 2.986 & 2.485 & 2.250 & 796 & 1077 & 1441 \\
\hline Tomatoes & 12.851 & 17.040 & 19.413 & 199 & 167 & 187 \\
\hline Potatoes & 9.042 & 9.761 & 15.152 & 282 & 292 & 240 \\
\hline
\end{tabular}




\section{Optimization}

The minimization of the virtual water inside the Nile valley in Egypt will be carried out using the linear programming techniques. Linear programing (LP) is a mathematical method for determining a way to achieve the best outcome (such as maximum profit or lowest cost) in a given mathematical model for some list of requirements represented as linear relationships. It is a specific case of mathematical programing (mathematical optimization [15].

This paper proposed that the proposed cropping pattern should produce the same level of current production of each crop and minimize the virtual water inside the whole Nile valley without any decrement in the total net return produced from the current cropping pattern.

\subsection{Objective Function}

Through this paper, the objective function can be mathematically expressed by Eq. 2:

$$
\mathbf{Z}_{\text {min }}=\sum_{\mathrm{i}=1}^{\mathbf{n}} \mathbf{V W}_{\mathrm{i}, \mathrm{k}} \times \mathbf{X}_{\mathrm{i}, \mathrm{k}} \ldots \ldots \ldots \ldots \ldots \ldots
$$

Where:

$\mathrm{Z}=$ Optimal solution

$\mathrm{VW}_{\mathrm{ik}}=$ Virtual water of crop (i), in zone (k)

$\mathrm{X}_{\mathrm{ik}}=$ Cultivated area of crop (i), in zone (k)

$\mathrm{n}=$ Number of crops cultivated in the three seasons (18 crops)

$\mathrm{k}=$ Number of zones $(3$ zones; lower $=1$, middle $=2$, and upper $=3$ )

\subsection{Constraints}

The objective function is subject to some constraints that are to be satisfied within the model; which include: Land availability constraint: the sum of land allocated for the cultivation of all crops must not exceed the total available land for cultivation as expressed by Eq. 3 .

$$
\sum_{i=1}^{m} \mathbf{X}_{i, y} \leq A t_{y}
$$

Where:

$\mathrm{X}_{\mathrm{i}, \mathrm{y}}=$ cultivated area of crop (i) at season (y)

$\mathrm{At}_{\mathrm{k}}=$ total cultivated area in season (y)

$\mathrm{m}=$ no. of crops in each season $(\mathrm{y})$. where, " $\mathrm{y}=1$ winter, $\mathrm{y}=2$ summer, $\mathrm{y}=3$ nili"

Water availability constraint: the sum of water requirements of all crop must not exceed the total available water for cultivation as expressed by Eq. 4.

$$
\sum_{i=1}^{n} W_{R_{i}} \leq W_{t}
$$

Where:

$\mathrm{WR}_{\mathrm{i}}=$ Water requirements of crop (i) per feddan.

$\mathrm{W}_{\mathrm{t}}=$ Total available water for cultivating different crops during whole year.

Production constraints: the sum of production for the same crop must be equal the current production of this crop (i.e the current production of rice was 5.88 million tons , the production constraints will set to be equal 5.88 million tons) as expressed by Eq. 5 .

$$
\sum_{i=1}^{z} X_{i} \times Y_{i}=P_{i}
$$

Where:

$\mathrm{Y}_{\mathrm{i}}=$ yield of crop (i) ton /fed.

$\mathrm{P}_{\mathrm{t}}=$ total production of crop (i) per ton.

Non-negativity constraint:

Can be expressed by Eq. 6:

$$
\mathbf{X}_{\mathbf{i}} \geq \mathbf{0}
$$




\section{Applying The Proposed Scenario}

The following section discusses the impact due to applying the proposed scenario which assumed the equity in production of the same crop. Table 9 shows the current and proposed water requirements, total cultivated area, and the total production of each crop.After applying the proposed scenario the following could be concluded:

- The total cultivated area inside the Nile valley of Sugarbeet decreased from 405 to 340 thousand feddans. The potatoes decreased from 171 to 137 thousand feddans in the winter season and tomatoes increased from 177 to 285 thousand feddans as shown in Fig 5.

- In the summer season, the total cultivated area of rice increased from 1,468 to 1,497 thousand feddans and the cultivated area of maize increased from 2,068 to 2,101 thousand feddans as shown in Fig 6.

- In nili season, the total cultivated area of maize decreased from 295 to 147 thousand feddans and the total cultivated area of potatoes increased from 55 to 133 thousand feddans as shown in Fig 7.

- The objective function decreased by about $5.59 \%$ comparing to the current status.

- The total cultivated area decreased by 204 thousand feddans. With decrement $1.96 \%$ comparing to the current status as shown in Table 9.

- The total water requirements decreased by 503 million cubic meters. With decrement $1.89 \%$ comparing to the current status as shown in Table 9.

- $\quad$ The proposed cropping pattern achieved the same net return as the current cropping pattern which was 58.3 Billion LE as shown in Table 9.

Table 9: Current and proposed water requirements, total cultivated area, and the total production of each crop

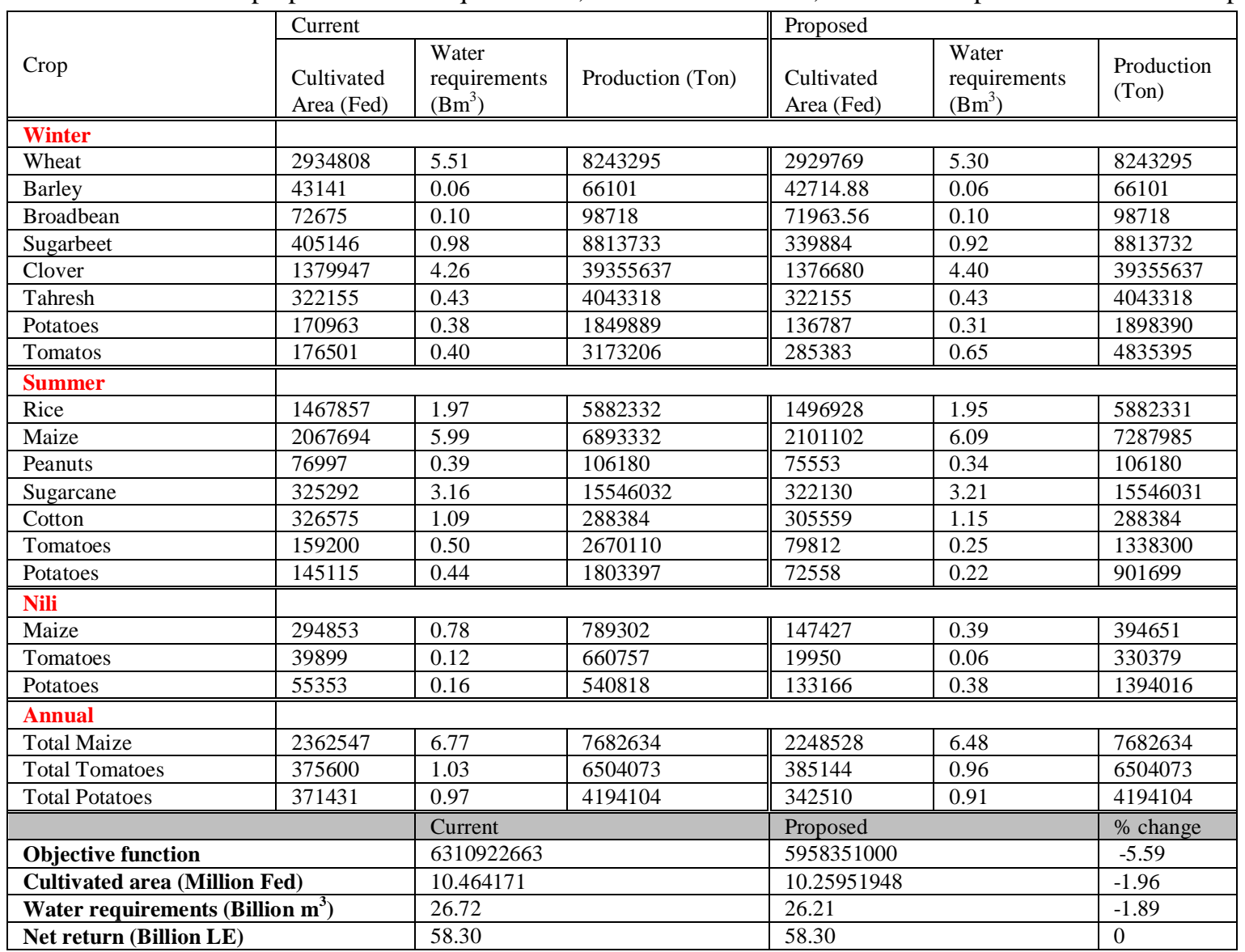




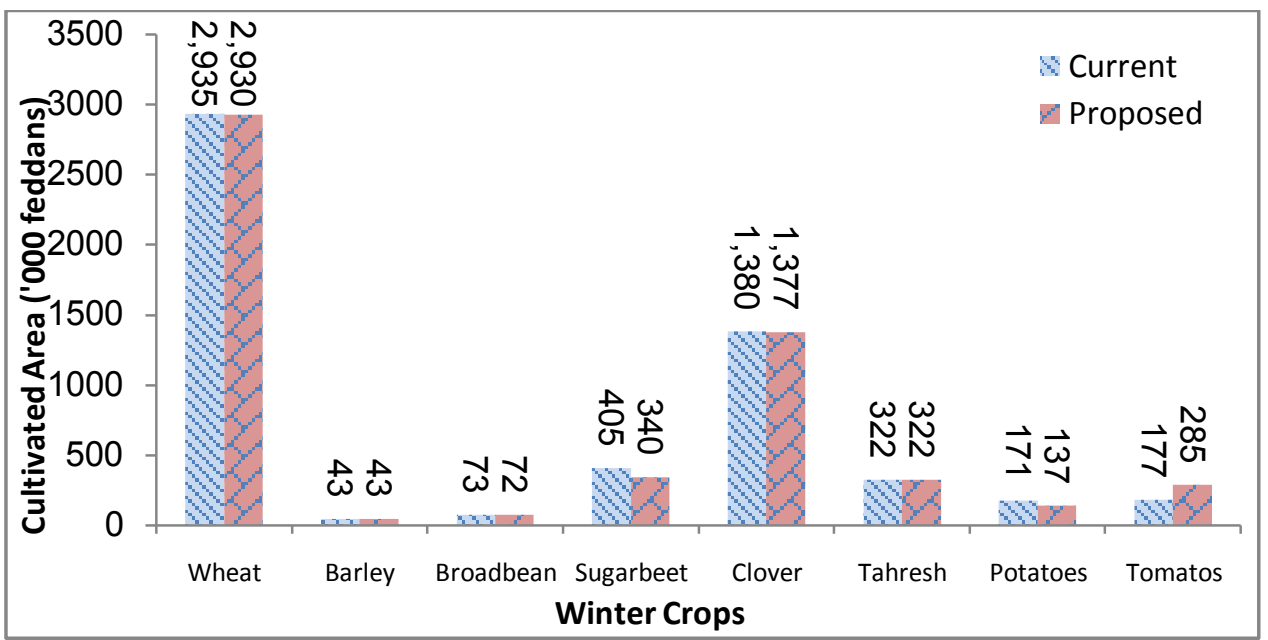

Fig. 5:The total current and proposed cultivated area of winter crops inside the Nile valley

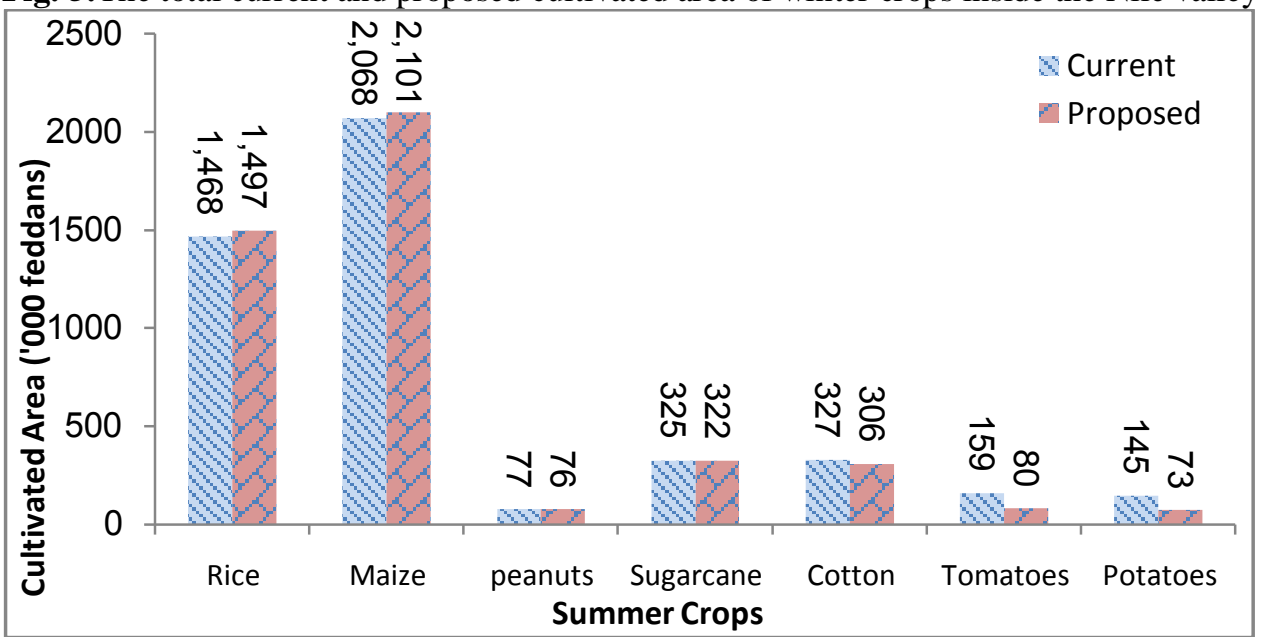

Fig. 6: The total current and proposed cultivated area of summer crops inside the Nile valley

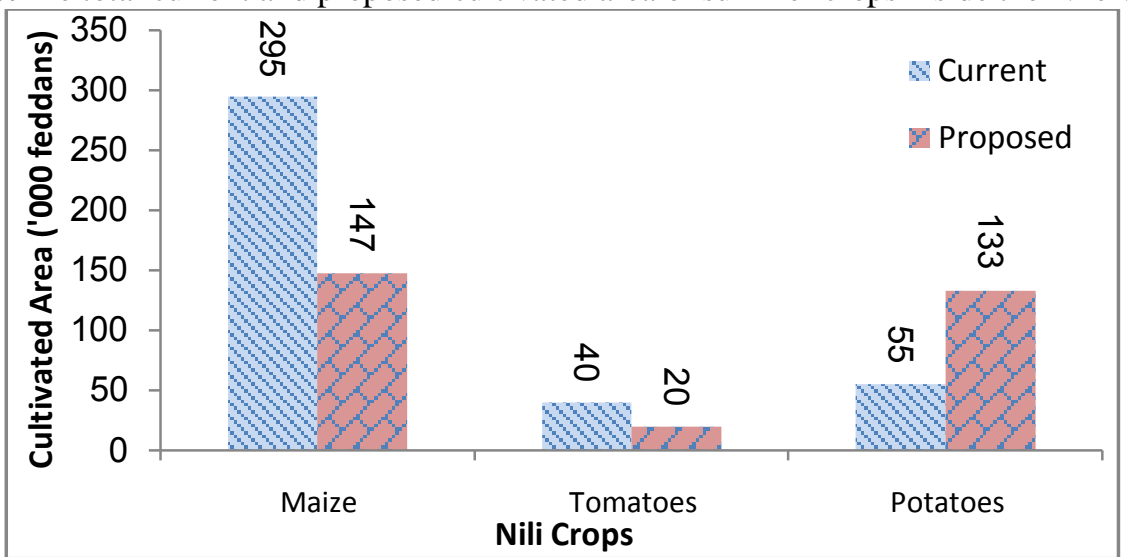

Fig. 7:The total current and proposed cultivated area of nili crops inside the Nile valley

\section{Conclusion And Recommendations}

According to the previous analysis and results produced from applying the prosed scenario the following could be concluded:

- The proposed cropping pattern economized in water requirements and cultivated area. The saved water and area could be used in cultivating more strategic crops to achieve self-sufficiency in Egypt.

- The proposed scenario decreased the objective function by $5.59 \%$, the total cultivated area decreased by 204 thousand feddans, and the total water requirements decreased by 503 million cubic meters.

- The study proved that there are alternative cropping patterns can economize the water requirements and cultivated area.

- Management of irrigation system through the participation of government and water user associations. 
- Changing cropping patterns should be on the basis of economic value of water in order to rational use of scarce water recourses considering socio-economic, environment, and political issues.

- Avoidance of the free cropping policy in Egypt to make it easier to develop new development strategies without restricted by Traditional farmers' behavior.

- The study recommended taking the virtual water content into consideration to build an effective decision support system to minimize the water requirements without any negative impact on socio-economic, environment, and political issues.

[2]. Ministry of Water Resources and Irrigation (MWRI), WaterCommunication Unit“Water: Egypt's Situation”, 1999.

[3]. World Water Council, E-Conference Synthesis"Virtual Water Trade - Conscious Choices", March, 2004.

[4]. Allan J.A. "Virtual water: a long term solution for water short Middle Eastern economies?" Paper presented at the 1997 British Association Festival of Science. Water and Development Session: University of Leeds.

[5]. Allan J.A. "Virtual water: a strategic resource. Global solutions to regional deficits." Groundwater 36 (4), 1998, 545-546.

[6]. El-Sadek A."Virtual water: an effective mechanism for integrated water resources management". Agricultural Sciences Vol.2, No.3, 2011, 248-261.

[7]. Doss M. and Milne G. " Water as an economic good: an approach to the Egyptianeconomy ". BeijerWorkshop on "Property Rights Structures and Environmental ResourceManagement” Egypt ,March, 2001.

[8]. Central agency for public mobilization and statistics (CAPMAS) "Egypt in Figures" 2014.

[9]. Attia B. "Assessment of Vulnerability and Adaptation of Water Resources to Climate Change in Egypt ."2009 http://www.arabwatercouncil.org/administrator/Modules/Events/IWRA\%20Egypt\%20Paper.pdf' found on the link since Aug 2014. [10]. Ministry of Water Resources and Irrigation (MWRI) "Integrated Water Resources Management Plan”, June 2005.

[11]. Ministry of Agriculture and Land Reclamation (MALR) "Agricultural Statistics Bulletin" 2013.

[12]. The World Bank. "Agricultural and Rural Development Data". Retrieved May 22, 2012.

[13]. http://data.worldbank.org/topic/agriculture-and-rural-development seen on 8/2014

[14]. Hoekstra A.Y., Chapagain A.K. "Water footprints of nations: water use by people as a function of their consumption pattern" . Water Resources Management 21 (1): 35-48. doi:10.1007/s11269-006-9039-x, 2007.

[15]. ICID-CIID "Multilingual Technical Dictionary on Irrigation and Drainage.", International Commission on Irrigation and Drainage, New DehliSeptember 2000.

[16]. Alevras D. and Manfred W., "Linear Optimization and Extensions: Problems and Solutions", Universitext, Springer-Verlag, 2001. 